\title{
Ecosystem carbon exchanges of a subtropical evergreen coniferous plantation subjected to seasonal drought, 2003-2007
}

\author{
X.-F. Wen ${ }^{1}$, H.-M. Wang ${ }^{1}$, J.-L. Wang ${ }^{2}$, G.-R. Yu ${ }^{1}$, and X.-M. Sun ${ }^{1}$ \\ ${ }^{1}$ Key Laboratory of Ecosystem Network Observation and Modeling, Institute of Geographic Sciences and Natural Resources \\ Research, Chinese Academy of Sciences, Beijing 100101, China \\ ${ }^{2}$ Qingdao Agricultural University, Qingdao 266109, China
}

Received: 27 May 2009 - Published in Biogeosciences Discuss.: 2 September 2009

Revised: 28 December 2009 - Accepted: 10 January 2010 - Published: 28 January 2010

\begin{abstract}
The behavior of whole ecosystems in humid climate zone in response to drought is less well documented. Continuous measurements of carbon dioxide and water vapor exchange using the eddy covariance technique during 20032007 were made above a subtropical evergreen coniferous plantation in Southeast China. Seasonal distribution of precipitation and temperature was inconsistent during the summer, which resulted in droughts frequently. Gross ecosystem photosynthesis (GEP), ecosystem respiration (RE) and net ecosystem production (NEP) showed clear seasonality, with low rates during droughts and in winter. With statistical significance, the monthly GEP and RE increased exponentially with air temperature, but the monthly NEP was less sensitive and only increased linearly with air temperature. However, the function response of monthly NEP and its components (GEP and RE) disappeared under high temperature and low soil moisture. Monthly and yearly RE showed a statistically linear and positive dependence on the corresponding GEP. Annual NEP varied among years from 306 to $430 \mathrm{~g} \mathrm{C} \mathrm{m}^{-2}$ (mean 395, SD 50). Interannual variability in NEP was controlled primarily by air temperature and the ratio of precipitation and evapotranspiration that affected the RE/GEP ratio, which varied between 0.76 and 0.81 (mean 0.78 , SD 0.02).
\end{abstract}

\section{Introduction}

Although not as commonly recognized, it is evident that ecosystem water balances are changing due to altered rainfall and evaporation patterns (Rambal and Debussche, 1995;

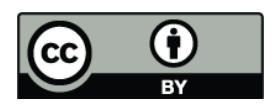

Correspondence to: X.-M. Sun

(sunxm@igsnrr.ac.cn)
Waple and Lawrimore, 2003; Reichstein et al., 2007). Enhanced drought may not only result from low annual rainfall, but more likely from a different rainfall distribution (Rambal and Debussche, 1995). There is growing evidence of a higher frequency of climatic extremes as a result of global climate change in recent years (e.g. Karl et al., 1995; Beniston, 2004). In the future warmer climate with increased air temperatures, future heat waves in areas of Europe and North America will become more intense, more frequent, and longer lasting (Meehl and Tebaldi, 2004). The changing precipitation regime accompanying with increased air temperatures has a profound impact on ecosystem carbon exchanges (e.g. Ciais et al., 2005; Niu et al., 2008). For example, a 30 percent reduction in gross ecosystem photosynthesis (GEP) occurred during 2003 Europe-wide heat and drought, which resulted in a strong anomalous net source of carbon dioxide ( $\left.0.5 \mathrm{Pg} \mathrm{C} \mathrm{yr}^{-1}\right)$ to the atmosphere (Ciais et al., 2005).

It's possible to measure the net carbon and water fluxes between ecosystems and the atmosphere based on the eddy covariance technique, which enable us to evaluate the seasonal and interannual variability in their exchanges and climatic controls (Baldocchi et al., 2003, 2008; Yu et al., 2006). However, the carbon balance at the ecosystem level (net ecosystem production, NEP) is the difference between gross ecosystem photosynthesis (GEP), which is carbon uptake by photosynthesis, and ecosystem respiration (RE), which is carbon losses by autotrophic and heterotrophic respiration (Schulze et al., 2000). The ecosystem carbon balance depends on how GEP and RE were affected relatively to each other. The challenge is that NEP is usually the measured term, but GEP and RE are the ecosystem-level processes that respond to biological and environmental cues. However, it's possible to statistically partition the NEP into GEP and RE, which allows a better interpretation of the fluxes in terms

Published by Copernicus Publications on behalf of the European Geosciences Union. 
of ecosystem carbon processes (e.g. Reichstein et al., 2005). Many flux records are just now long enough to allow analysis of the complex, interacting biotic and abiotic controls on the carbon cycle of terrestrial ecosystems. Recently, some flux studies at least 5 years in duration have been published (e.g. Goulden et al., 1996; Barford et al., 2001; Hollinger et al., 2004; Haszpra et al., 2005; Saigusa et al., 2005; Barr et al., 2007; Beringer et al., 2007; Dunn et al., 2007; Grünwald et al., 2007; Ma et al., 2007; Schwalm et al., 2007; Urbanski et al., 2007; Hirara et al., 2008). Such kinds of long-term flux measurements enable us to quantify how temperature fluctuations and drought conditions affect NEP and its components (Baldocchi, 2008). Droughts are relatively unpredictable in timing, duration and intensity in humid climate zones. Therefore, the behavior of whole ecosystems in response to drought is less well documented (Baldocchi, 2008). It is a very important way to explore the drought effects on the ecosystem carbon exchanges based on the natural drought conditions (e.g. Baldocchi, 2005).

The objective of our study was to evaluate the magnitude and cause of both seasonal and interannual variation in GEP, RE and NEP between the atmosphere and a subtropical evergreen coniferous plantation subjected to seasonal drought during 2003-2007 in Southeast China. The inconsistent distribution of precipitation and temperature allows summer droughts frequently (Wen et al., 2006; Yu et al., 2008a, b). There is a pronounced spectral gap in ecosystem carbon and water exchanges at the monthly scale, which makes it appropriate time step to capture seasonal and phenological change (Baldocchi et al., 2001).

\section{Materials and methods}

\subsection{Site description}

As a part of the ChinaFLUX network, the eddy fluxes of carbon dioxide and water vapor were measured at Qianyanzhou site $\left(26^{\circ} 44^{\prime} 29^{\prime \prime} \mathrm{N}, 115^{\circ} 03^{\prime} 29^{\prime \prime} \mathrm{E}\right.$, and elevation $\left.102 \mathrm{~m}\right)$ in Southeast China. The site is located in the subtropical continental monsoon region. According to the long-term records of the adjacent weather station (1985-2007, data source: database of Chinese Ecosystem Research Network), the mean annual air temperature is $17.9^{\circ} \mathrm{C}$, and the mean annual precipitation is $1475 \mathrm{~mm}$. Generally, the area is subject to episodic summer droughts. During the investigated period, extremely dry summers occurred in 2003 and 2007. The main wind directions are north-northwest during the winter, and south-southeast during the summer. This plantation, planted in 1985, around the site is on undulating terrain with slopes between the crest and valley of the hill from 2.8 to 13.5 degrees. The topography map around the tower is shown in Fig. 1.

The tree density is 1463 stems ha $^{-1}$, and the total biomass is about $106 \mathrm{tha}^{-1}$, and the maximum of leaf area index is

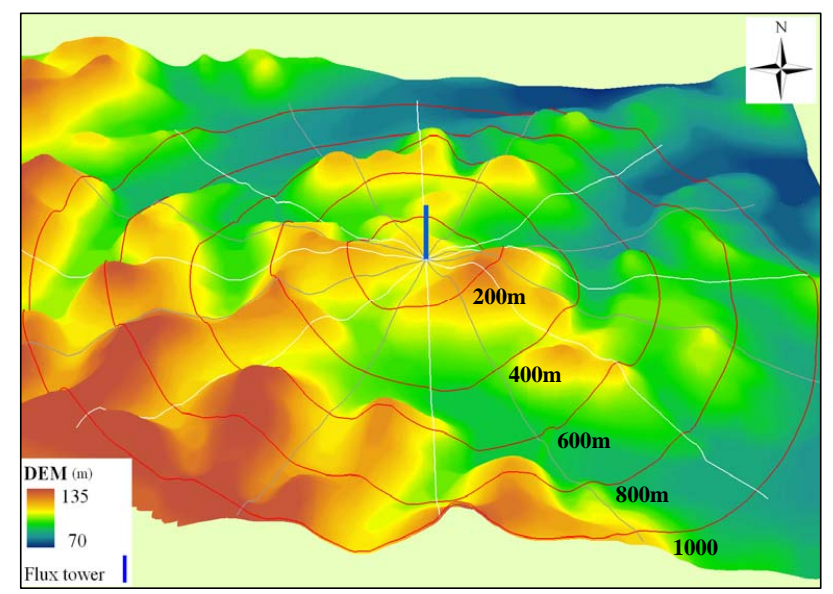

Fig. 1. Area relief map of the Qianyanzhou site based on Digital Elevation Model (DEM). The tower is located in the middle of the map, with $200 \mathrm{~m}$ equidistance lines.

$5.6 \mathrm{~m}^{2} \mathrm{~m}^{-2}$, and the mean canopy height is about $13 \mathrm{~m}$. The plantation is dominated by Slash pine (Pinus elliottii), Masson pine (Pinus massoniana) and Chinese fir (Cunninghamia lanceolata). A survey made in 2004 around the flux tower indicated that the mean tree height, diameter at breast height, and density of Slash pine were about $12.0 \mathrm{~m}, 15.8 \mathrm{~cm}$ and 809 stems ha $^{-1}$, respectively, and were about $9.5 \mathrm{~m}, 13.1 \mathrm{~cm}$ and 444 stems ha $^{-1}$ for Masson pine, respectively, and were about $10.9 \mathrm{~m}, 13.2 \mathrm{~cm}$ and $210 \mathrm{stems} \mathrm{ha}^{-1}$ for Chinese fir, respectively. The soil parent material consists of red sandstone and mud stone, and soils are mainly red earth, which weathered from red sand rock (Wang et al., 2004). Soil texture is divided into $2.0-0.05 \mathrm{~mm}$ (17\%), 0.05-0.002 $\mathrm{mm} \mathrm{(68 \% )} \mathrm{and}$ $<0.002 \mathrm{~mm}(15 \%)$. Further details were available in the literatures (Wen et al., 2006; Huang et al., 2007; Yu et al., 2008a, b).

\subsection{Measurements and instrumentation}

The above-canopy flux system, mounted at $39.6 \mathrm{~m}$ on a tower, consisted of a 3-D sonic anemometer (Model CSAT3, Campbell Scientific Inc., Logan, UT, USA) and an LI7500 open-path $\mathrm{CO}_{2} / \mathrm{H}_{2} \mathrm{O}$ analyzer (Model LI-7500, Licor Inc., Lincoln, NE, USA). The LI7500 was calibrated twice or thrice in every year by pure nitrogen gas, $\mathrm{CO}_{2}$ standard gas and dew point generator (Model LI-610, Licor Inc., Lincoln, NE, USA). Flux variables were sampled at $10 \mathrm{~Hz}$ by a CR5000 datalogger (Model CR5000, Campbell Scientific Inc.) with 30 min mean fluxes calculated.

Routine radiation measurements were made using a fourcomponent net radiometer (Model CNR-1, Kipp \& Zonnen, Delft, The Netherlands), a pyranometer (Model CM11, Kipp \& Zonen) and a quantum sensor of photosynthetically active radiation (Model LI190SB, Licor Inc.). Air temperature and relative humidity sensors (Model HMP45C, Campbell 
Scientific Inc.) were mounted in ventilated shields at heights of 1.6, 7.6, 11.6, 15.6, 23.6, 31.6 and $39.6 \mathrm{~m}$ above the ground. Soil temperatures were measured at five depths (2, $5,20,50$ and $100 \mathrm{~cm}$ ) with thermocouples (105T and 107L, Campbell Scientific Inc.). Soil water contents were measured with three TDR probes (Model CS615-L, Campbell Scientific Inc.) at depths of 5, 20 and $50 \mathrm{~cm}$. Rainfall was monitored with a rain gauge (Model 52203, RM Young Inc., Michigan, USA). Meteorological variables were sampled at $1 \mathrm{~Hz}$ with $30 \mathrm{~min}$ averages calculated by three CR10X dataloggers (Model CR10XTD, Campbell Scientific Inc.) and a CR23X datalogger (Model CR23XTD, Campbell Scientific Inc.) with a 25-channel solid-state multiplexer (Model AM25T, Campbell Scientific Inc.).

\subsection{Flux calculation and correction}

Carbon dioxide and water vapor fluxes were measured since late August 2002 using the eddy covariance technique. The flux of NEP $\left(\mathrm{mg} \mathrm{CO}_{2} \mathrm{~m}^{-2} \mathrm{~s}^{-1}\right)$ or evapotranspiration (ET, $\mathrm{g} \mathrm{H}_{2} \mathrm{O} \mathrm{m}^{-2} \mathrm{~s}^{-1}$ ) between the biosphere and the atmosphere was calculated,

$F_{\mathrm{c}}=-\left(\overline{w^{\prime} \rho_{\mathrm{c}}^{\prime}\left(z_{\mathrm{r}}\right)}+\int_{0}^{z_{\mathrm{r}}} \frac{\partial \bar{\rho}_{\mathrm{c}}}{\partial t} d z\right)$

where the first term on right-hand side is the eddy flux for carbon dioxide or water vapour, the second term is the storage of carbon dioxide or water vapour below the height of observation $\left(z_{\mathrm{r}}\right)$, and all advective terms in the mass conservation equation were ignored.

Spurious data were removed from the dataset if the instrument performance and experimental conditions were abnormal. The problems were largely related to rainfall, water condensation, system failure, or insufficient turbulent mixing during the night (e.g. Wen et al., 2005). Generally, 56.3\% of the study site half-hourly NEP dataset was excluded. In this study, the detailed protocols of flux calculation and correction for carbon dioxide and water vapour were described as following. First of all, for the raw time series, physically impossible values could be excluded for the calculation of averages, variance and covariance in half-hour intervals. A spike detection algorithm on the raw time series followed the paper by Vickers and Mahrt (1997). Any value, which exceeds 5.5 times standard deviations in a window of 10 values, was labeled as a spike. Values, which were detected as spikes, could be excluded for later calculations. The raw time series would be shorten by the number of missing values in this case. It was important that the proportion of real measurements in the raw time series was large enough to be representative. Herein, we adopted at least $90 \%$ real measurements in a half-hour interval. The characteristics of the instrument and the quality and reliability of flux measurements were examined by calculation of power- and cospectra (Wen et al., 2005; Sun et al., 2006b). Secondly, for the time series at half-hour intervals, planar fit rotation was applied to the wind components to remove the effect of instrument tilt or irregularity on the airflow at the monthly intervals (Wilczak et al., 2001). The instrument effects that damp the high-frequency fluctuations including the dynamic frequency response of the sonic anemometer and the IRGA, the scalar path averaging, and the sensor separation were corrected (Kaimal et al., 1972; Moore, 1986; Aubinet et al., 2000). Correction was made for the effect of fluctuations of air density on the fluxes of $\mathrm{CO}_{2}$ and water vapor (Webb et al., 1980; Leuning, 2004). The effect of the $\mathrm{CO}_{2}$ storage below the height of observation was corrected using the temporal change in $\mathrm{CO}_{2}$ concentration above the canopy measured with an LI7500 open-path $\mathrm{CO}_{2} / \mathrm{H}_{2} \mathrm{O}$ analyzer (Yu et al., 2008b). The effect of the water vapour storage below the height of observation was corrected using the air temperature and relative humidity profile measurements. Thirdly, an overall quality flag system was created for NEP and ET fluxes according the steady state test and integral turbulence characteristics test (Foken and Wichura, 1996). These overall flags had the value 1 for highest quality, 2 for good quality and 3 for bad quality data. All NEP and ET fluxes with the value 3 , either steady state or integral turbulence characteristics deviating in excess of $100 \%$, were excluded. In addition, the algorithm used to detect the spikes of NEP was also done based on the method of Papale et al. (2006), and it was applied to blocks of 13 days and separately for daytime and nighttime $\mathrm{CO}_{2}$ flux dataset. Lastly, to avoid possible underestimation of the fluxes under stable conditions during the night, the effect of friction velocity $u_{*}$ was examined statistically for each year according to the method of Reichstein et al. (2005). When the value of $u_{*}$ was less than $0.19 \mathrm{~m} \mathrm{~s}^{-1}$, which was the maximum $u_{*}$ threshold among 2003-2007, the values observed of NEP and ET in the night (Solar elevation angle $<0$ ) were excluded. Sensitivity analysis of $u_{*}$ on annual fluxes of NEP, GEP and RE showed that they generally varied less than $1 \%$ when $u_{*}$ increased or decreased by $0.01 \mathrm{~m} \mathrm{~s}^{-1}$ based on the $u_{*}$ threshold. Likewise, positive NEP fluxes at night (i.e. apparent photosynthesis) were also taken out of the database.

\subsection{Gap filling and flux partitioning}

Data gaps were unavoidable in long-term and continuous measurements. The data gaps of NEP were filled mainly by the nonlinear regressions method (Falge et al., 2001). For small gaps $(<2 \mathrm{~h})$, the missing data were linearly interpolated. For larger gaps, the missing daytime NEP were estimated using the Michaelis-Menten equation with an independent 10-day window,

$\mathrm{NEP}=\frac{\alpha Q_{\mathrm{P}} \mathrm{GEP}_{\mathrm{sat}}}{\alpha Q_{\mathrm{P}}+\mathrm{GEP}_{\mathrm{sat}}}-\mathrm{RE}_{\text {day }}$

where $\alpha$ is ecosystem apparent quantum yield (mg $\mathrm{CO}_{2} \mu \mathrm{mol}^{-1}$ ), and $Q_{\mathrm{p}}$ is photosynthetic photon flux density $\left(\mu \mathrm{mol} \mathrm{m}{ }^{-2} \mathrm{~s}^{-1}\right)$, and $\mathrm{GEP}_{\text {sat }}$ is the asymptotic GEP at 
saturating light, and $\mathrm{RE}_{\text {day }}$ is the average value of daytime $\mathrm{RE}$ (both $\mathrm{mg} \mathrm{CO}_{2} \mathrm{~m}^{-2} \mathrm{~s}^{-1}$ ).

The nighttime NEP was defined as nighttime ecosystem respiration ( $\mathrm{RE}_{\text {night }}, \mathrm{mg} \mathrm{CO}_{2} \mathrm{~m}^{-2} \mathrm{~s}^{-1}$ ). The missing $\mathrm{RE}_{\text {night }}$ were estimated as a function of soil temperature and soil moisture with a yearly interval (Reichstein et al., 2002),

$\mathrm{RE}_{\text {night }}=R_{\mathrm{ref}}\left(b_{1}+b_{2} \mathrm{Sw}\right)^{\frac{T_{\text {soil }}-T_{\text {ref }}}{10}}$

where $R_{\text {ref }}, b_{1}$ and $b_{2}$ are fitted parameters, and $T_{\text {ref }}$ is fixed to $15^{\circ} \mathrm{C}$, and $R_{\text {ref }}$ stands for the ecosystem respiration rate $\left(\mathrm{mg} \mathrm{CO}_{2} \mathrm{~m}^{-2} \mathrm{~s}^{-1}\right)$ at the reference temperature, and $\mathrm{Sw}$ is the soil water content $\left(\mathrm{m}^{3} \mathrm{~m}^{-3}\right)$ at $5 \mathrm{~cm}$ depth, and $T_{\text {soil }}$ is the soil temperature $\left({ }^{\circ} \mathrm{C}\right)$ at $5 \mathrm{~cm}$ depth.

To estimate the gross ecosystem photosynthesis (GEP, $\mathrm{mg} \mathrm{CO} \mathrm{m}^{-2} \mathrm{~s}^{-1}$ ), the daytime ecosystem respiration $\left(\mathrm{RE}_{\text {day }}, \mathrm{mg} \mathrm{CO}_{2} \mathrm{~m}^{-2} \mathrm{~s}^{-1}\right)$ were estimated by the extrapolation of the function relationship between the nighttime ecosystem respiration $\left(\mathrm{RE}_{\text {night }}, \mathrm{mg} \mathrm{CO} \mathrm{Cm}^{-2} \mathrm{~s}^{-1}\right.$ ) and soil temperature and water content. In addition, for small gaps of ET $(<2 \mathrm{~h})$, the missing data were linearly interpolated. For larger gaps, the missing ET values were filled by the combined look-up table and mean diurnal variation methods (Reichstein et al., 2005).

\section{Results}

\subsection{Seasonal and interannual variations of environmental conditions}

Figure 2 demonstrates the seasonal variations of monthly air temperature, vapour pressure deficit (VPD), precipitation and soil water contents. The air temperature showed single peak variation with the maximum more than $28^{\circ} \mathrm{C}$ in July, corresponding with the VPD more than $1.2 \mathrm{kPa}$ (Fig. 2a). However, rainfall variability was obvious due to annual rainfall and altered rainfall patterns (Fig. 2b). Generally, precipitation decreased in the midseason (July), to some degree, whereas the air temperature reached the maximum. The asynchronous seasonality between temperature and precipitation during the midseason offered a possibility of frequent droughts. The seasonal variations of soil water contents in different depths were closely related to the rainfall variability. They showed strong seasonal patterns, generally with net water gains during the preseason and net water losses during the midseason and postseason. The soil water contents in different depths showed obviously declining trends during the midseason or postseason.

Table 1 lists the annual net radiation, air temperature, precipitation $(P)$, evapotranspiration (ET), and water balance in$\operatorname{dex}(P$-ET, and $P /$ ET). The annual precipitation in 2003 was the lowest among the 5-year records accompanying with the lowest water balance index, followed by the second lowest in 2007. Meanwhile, the annual air temperature in 2003 and
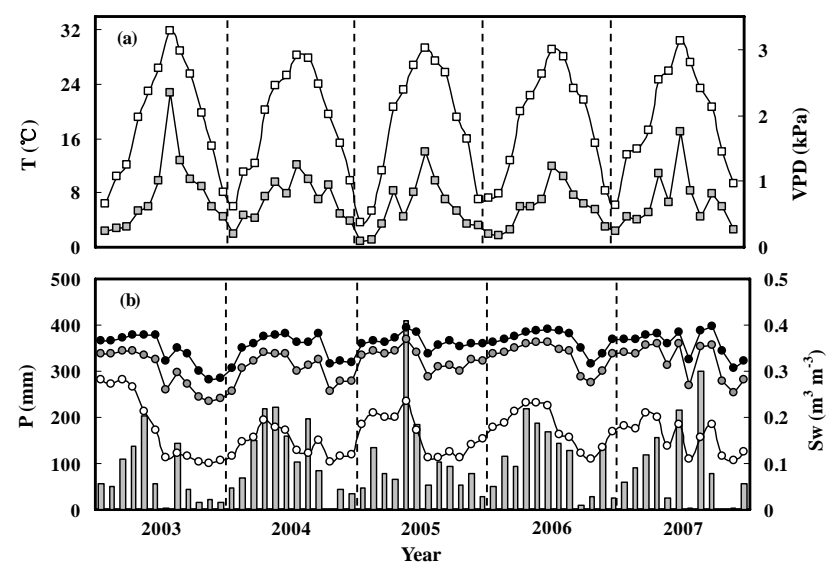

Fig. 2. Seasonal and interannual variations of monthly (a) air temperature ( $T$, blank squares) and vapour pressure deficit (VPD, gray squares) at the height of the eddy covariance system, and (b) precipitation ( $P$, gray bars) and soil water contents $(\mathrm{Sw}, 5 \mathrm{~cm}$ : blank circles; $20 \mathrm{~cm}$ : gray circles; $50 \mathrm{~cm}$ : black circles) from 2003 to 2007 at Qianyanzhou site.

2007 were the highest. In comparison, the annual precipitation in 2004, 2005 and 2006 were similar with the higher water balance index, but the annual air temperature and net radiation in 2005 were the lowest.

This plantation was subject to episodic summer droughts during the investigated period (Fig. 2). Carbon assimilation and plant growth rate were obviously suppressed during the summer in 2003 and 2007 because droughts occurred extremely. Under such conditions, Slash pine, Masson pine and Chinese fir even appeared senescence in 2003, but that of Slash pine was more serious than the other two (Wen et al., 2006). The leaf area index of whole canopy also showed a descending trend (Huang et al., 2007).

\subsection{Seasonality and interannual variability of GEP, RE and NEP}

Monthly and seasonal anomalies reflect primarily weather and climate variations (Goulden et al., 1996; Barford et al., 2001). Figure 3 shows the seasonal and interannual variations of 30-day running-mean GEP, RE and NEP. Note that NEP and its components (GEP and RE) showed clear seasonality, with low rates varying with drought severity and history during summer and in winter. The GEP, RE and NEP in 2003 and 2007 showed an obviously declining trend during the midseason, and recovered to increase, to some extent, during the postseason (Fig. 3). Especially, in 2003, this plantation even acted as the net ecosystem carbon source during the summer.

Table 2 gives the annual GEP, RE and NEP totals and the RE/GEP ratios. Annual GEP varied from 1629 to $1857 \mathrm{~g} \mathrm{C} \mathrm{m}^{-2}$ (mean 1779, SD 107), and annual RE varied from 1286 to $1447 \mathrm{~g} \mathrm{C} \mathrm{m}^{-2}$ (mean 1384, SD 75), and 
Table 1. Interannual variability in annual net radiation $\left(R_{\mathrm{n}}\right)$, air temperature $(T)$, total precipitation $(P)$, evapotranspiration $($ ET) and water balance $(P$-ET, $P /$ ET) from 2003 to 2007 at Qianyanzhou site.

\begin{tabular}{lcccccc}
\hline Year & $\begin{array}{c}R_{\mathrm{n}} \\
\mathrm{MJ} \mathrm{m}^{-2} \mathrm{yr}^{-1}\end{array}$ & $\begin{array}{c}T \\
{ }^{\circ} \mathrm{C}\end{array}$ & $\begin{array}{c}P \\
\mathrm{~mm} \mathrm{yr}^{-1}\end{array}$ & $\begin{array}{c}\mathrm{ET} \mathrm{mm} \\
\mathrm{yr}^{-1}\end{array}$ & $\begin{array}{c}P \text {-ET } \\
\mathrm{mm} \mathrm{yr}^{-1}\end{array}$ & $\begin{array}{c}P / \mathrm{ET} \\
\text { dimensionless }\end{array}$ \\
\hline 2003 & 2849 & 18.9 & 855 & 761 & 94 & 1.12 \\
2004 & 2866 & 18.6 & 1325 & 860 & 464 & 1.54 \\
2005 & 2621 & 17.9 & 1330 & 557 & 779 & 2.42 \\
2006 & 2658 & 18.4 & 1310 & 694 & 616 & 1.89 \\
2007 & 2777 & 18.9 & 1107 & 868 & 239 & 1.28 \\
$2003-2007$ & & & & & & \\
Mean \pm SD & $2754 \pm 111$ & $18.5 \pm 0.4$ & $1185 \pm 207$ & $747 \pm 131$ & $439 \pm 277$ & $1.65 \pm 0.52$ \\
\hline
\end{tabular}

Table 2. Interannual variability in annual gross ecosystem photosynthesis (GEP), ecosystem respiration (RE), net ecosystem production (NEP) and the RE/GEP ratios from 2003 to 2007 at Qianyanzhou site.

\begin{tabular}{lcccc}
\hline Year & $\begin{array}{c}\text { GEP } \\
\mathrm{g} \mathrm{C}^{-2} \mathrm{yr}^{-1}\end{array}$ & $\begin{array}{c}\mathrm{RE} \\
\mathrm{g} \mathrm{C} \mathrm{m}^{-2} \mathrm{yr}^{-1}\end{array}$ & $\begin{array}{c}\text { NEP } \\
\mathrm{g} \mathrm{C} \mathrm{m}^{-2} \mathrm{yr}^{-1}\end{array}$ & $\begin{array}{c}\text { RE/GEP } \\
\text { dimensionless }\end{array}$ \\
\hline 2003 & 1702 & 1286 & 416 & 0.76 \\
2004 & 1858 & 1447 & 410 & 0.78 \\
2005 & 1629 & 1323 & 306 & 0.81 \\
2006 & 1852 & 1440 & 412 & 0.78 \\
2007 & 1857 & 1427 & 430 & 0.77 \\
$2003-2007$ & & & & $0.78 \pm 0.02$ \\
Mean \pm SD & $1779 \pm 107$ & $1384 \pm 75$ & $395 \pm 50$ & 0.075 \\
\hline
\end{tabular}

annual NEP varied from 306 to $430 \mathrm{~g} \mathrm{C} \mathrm{m}^{-2}$ (mean 395, SD $50)$. The annual RE/GEP ratios ranged from 0.76 to 0.81 (mean 0.78, SD 0.02). The annual NEP in 2003 and 2007 did not show a clear decline even with extremely dry summer. The NEP was the lowest in 2005 because of the lowest net radiation (Table 1), although the lowest air temperature might also decrease respiration depending on substrate availability, temperature and moisture. Ma et al. (2008) reported that the observed NEP in 2004 and 2005 was 497 and $375 \mathrm{~g} \mathrm{C} \mathrm{m}^{-2} \mathrm{yr}^{-1}$, respectively, through biometric measurements in adjacent plot of our flux tower. They were comparable, but higher than our NEP results by the eddy covariance technique, with 416 and $306 \mathrm{~g} \mathrm{C} \mathrm{m}^{-2} \mathrm{yr}^{-1}$ in 2004 and 2005 (Table 2).

\subsection{Response of GEP, RE and NEP to temperature}

Figure 4 illustrates the response of monthly and yearly GEP, RE and NEP to air temperature. Figure 4a showed that monthly GEP and RE increased exponentially with air temperature while air temperature was lower than $28^{\circ} \mathrm{C}$, accompanying with relatively higher soil moisture. The average of soil water content was $0.168 \mathrm{~m}^{3} \mathrm{~m}^{-3}$ when air temperature was below $28^{\circ} \mathrm{C}$. More importantly, NEP was less sen- sitive to air temperature than GEP and RE. Monthly NEP only increased linearly with air temperature. Moreover, such kinds of function relationship failed when air temperature was higher than $28^{\circ} \mathrm{C}$, accompanying with relatively lower soil moisture. The average of soil water content was $0.125 \mathrm{~m}^{3} \mathrm{~m}^{-3}$ when air temperature was above $28^{\circ} \mathrm{C}$. Similarly, RE is an exponential function of air or soil temperature, with rates further modulated by soil moisture (Reichstein et al., 2002; Powell et al., 2008). In addition, the response of monthly GEP, RE and NEP to vapor pressure deficit was similar to that of air temperature (data are not shown).

Figure $4 \mathrm{~b}$ showed that it was held that yearly NEP increased linearly with air temperature. Annual air temperature was almost sufficiently high during 2003-2007, varying only from 17.9 to $18.9^{\circ} \mathrm{C}$ (mean 18.5 , SD 0.4 ) (Table 1). Although the interannual variation of air temperature was within $1{ }^{\circ} \mathrm{C}$, this linear relationship was statistically significant. Air temperature dominated the processes of NEP at the monthly and yearly scales (Fig. 4). However, there were no statistically significant relationship between yearly GEP and RE and air temperature. 

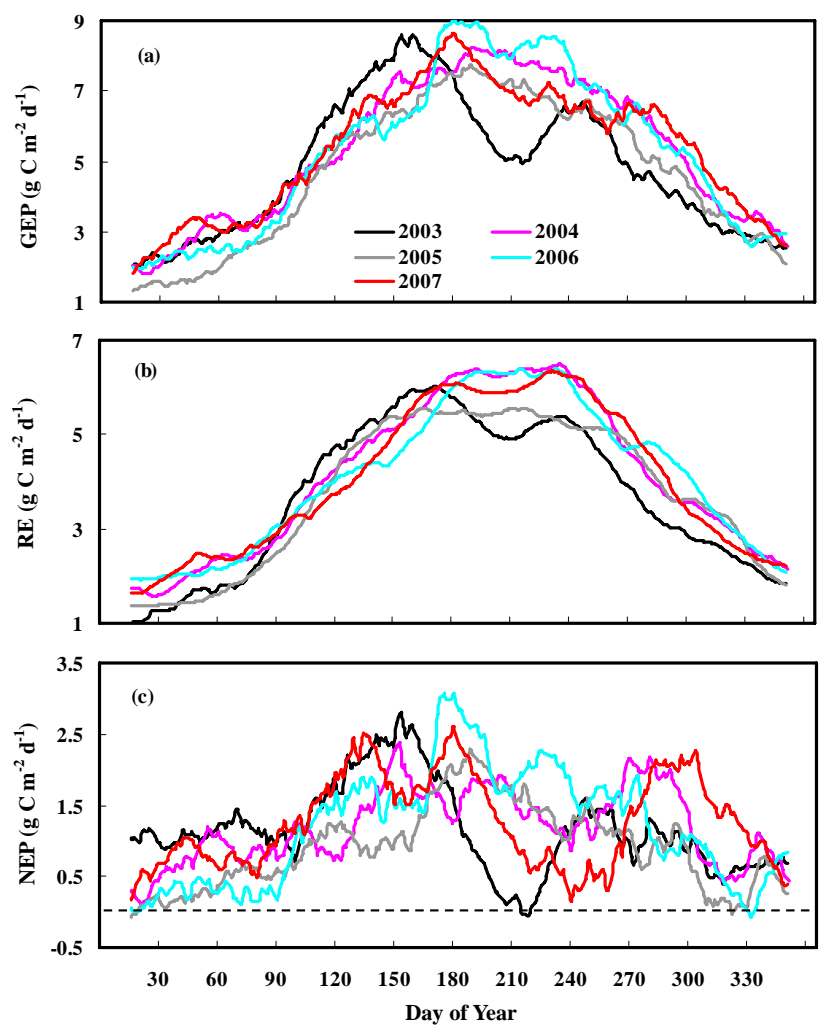

Fig. 3. Seasonal and interannual variations of 30-day running-mean (a) gross ecosystem photosynthesis (GEP), (b) ecosystem respiration (RE) and (c) net ecosystem production (NEP) from 2003 to 2007 at Qianyanzhou site.

\subsection{Response of GEP, RE and NEP to soil water content}

Figure 5 illustrates the response of monthly GEP, RE and NEP to soil water content. There are two distinct groups of data. In the first group for air temperature larger than $16^{\circ}$, the correlations of soil water content with GEP and RE were quadratic. The relationships were statistically significant. However, the correlation of NEP with soil water content was not statistically significant. In the second group for air temperature less than $16^{\circ}$, there were no obvious correlations between soil water content and GEP, RE and NEP. Especially, there were also no statistically significant relationships between yearly GEP, RE, NEP and soil water content (data are not shown).

\section{Discussions}

\subsection{Effects of drought on GEP, RE and NEP}

Due to the influence of Asian monsoon climate, this site is subject to extreme drought in the summer frequently (Wen et al., 2006; Sun et al., 2006a). The variation of NEP is complex, because NEP integrates two interactive processes, GEP

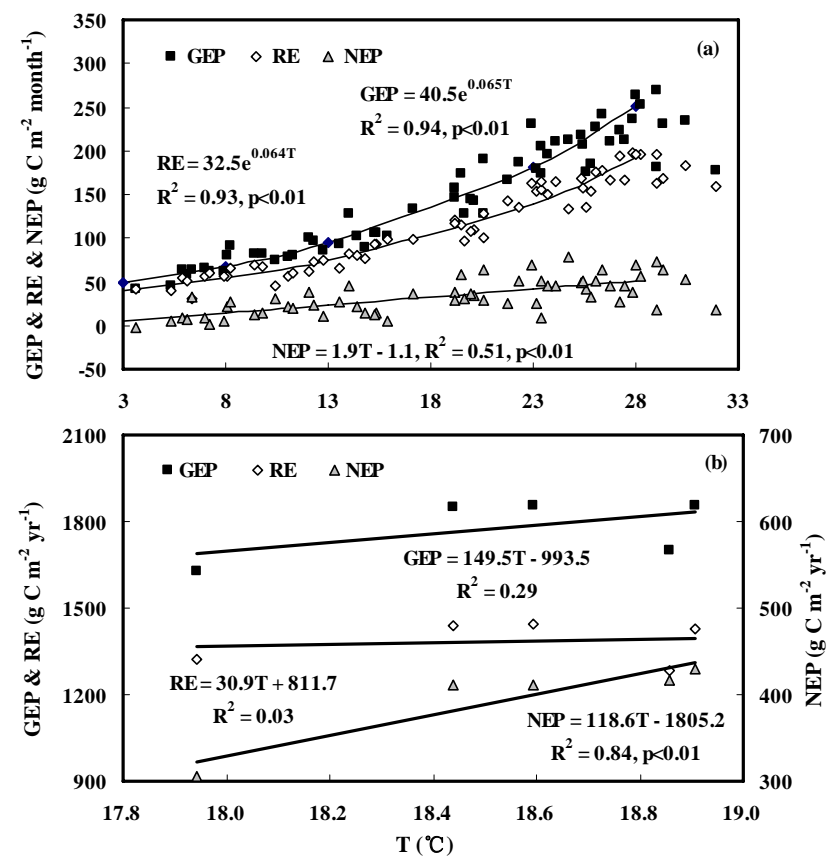

Fig. 4. Response of (a) monthly and (b) yearly gross ecosystem photosynthesis (GEP), ecosystem respiration (RE) and net ecosystem production (NEP) to air temperature $(T)$ during 2003 to 2007 at Qianyanzhou site.

and RE, both of which respond independently to climate (e.g. Reichstein et al., 2002; Barr et al., 2007). RE is controlled by temperature, soil water content and substrate availability (including recent photosynthetic assimilates; it is coupled to GEP), while GEP is mainly controlled by radiation, air temperature, water vapor deficit, the water amount of root uptake, the amount of leaves in the canopy (leaf area index) and the distribution and function of these leaves in different parts of the canopy (e.g. Reichstein et al., 2002). The interactions of GEP and RE were more important.

The effect of drought on NEP varied with drought severity and history. During the early days of drought, soil drying decreases the activities of roots and soil microorganisms and inhibits their respiration, since sufficient water is essential for normal root and microbial function (Wen et al., 2006). At the same time, water that could be withdrawn from the deeper soil column by roots supported photosynthesis. The water in the deep soil is exhausted with the process of the intensified drought (Mi et al., 2009). Severe and persistent drought suppressed NEP by suppressing GEP to some degree that equaled or exceeded the large suppression in RE during the seasonal drought period (Fig. 3). Carbon assimilation by the canopy decreases remarkably as soil dries up, and consequently supply of the carbohydrates to the below-ground biocommunity is reduced accordingly (Reichstein et al., 2002). The declining degree of NEP is determined by the accumulation of soil moisture deficits and a co-occurrence of high 

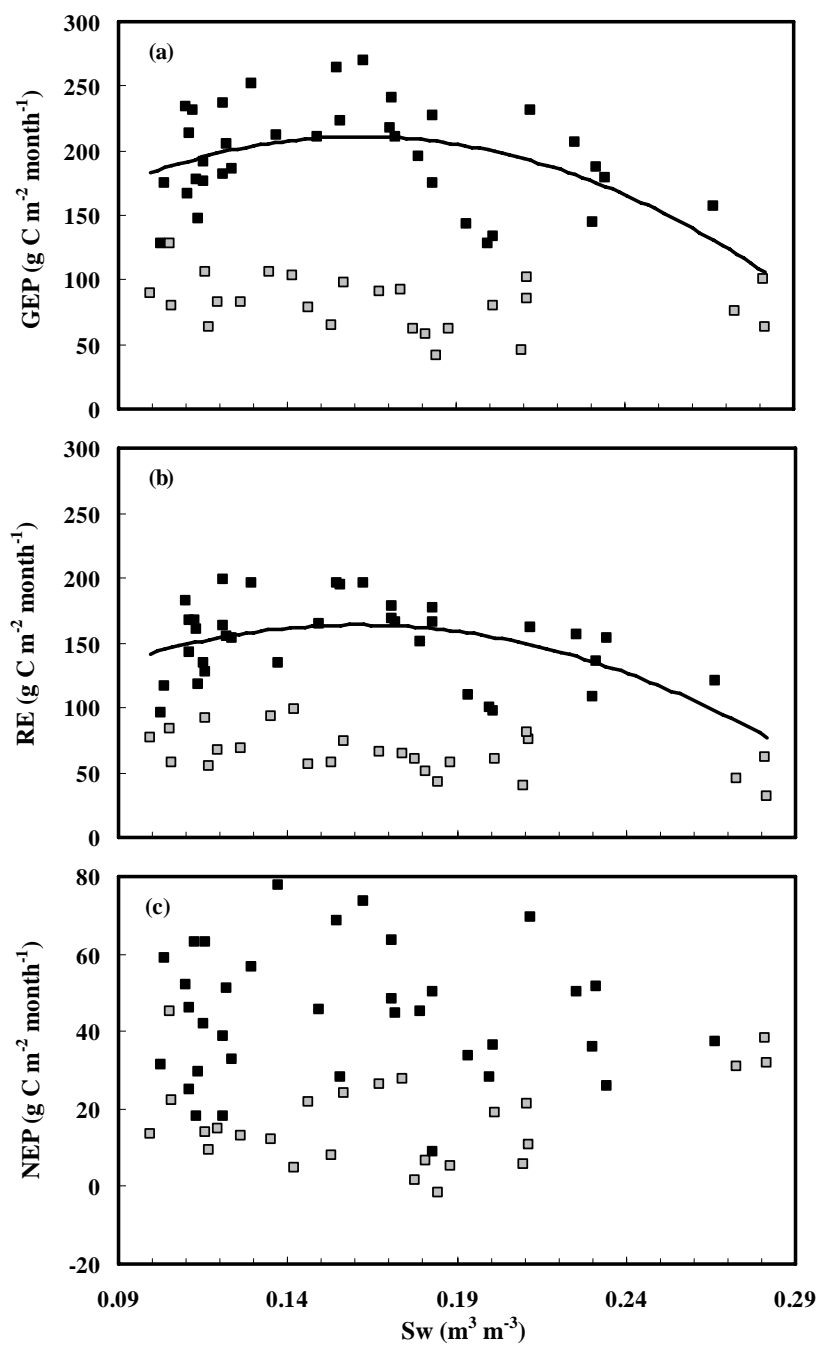

Fig. 5. Response of monthly gross ecosystem photosynthesis (GEP), ecosystem respiration (RE) and net ecosystem production (NEP) to soil water content $(\mathrm{Sw}, 5 \mathrm{~cm})$ during 2003 to 2007 at Qianyanzhou site. GEP, RE and NEP were marked by black squares while air temperature was larger than $16^{\circ}$, and gray squares while temperature less than $16^{\circ}$. Least-squares quadratic regressions of the data marked by the black squares were given by the solid line, and (a) $R^{2}=0.17, p<0.01$ and (b) $R^{2}=0.18, p<0.01$.

temperatures (Wen et al., 2006). GEP showed low rates during seasonal drought because higher temperature and lower soil water content events decreases enzyme kinetics well below their optimum (Mi et al., 2009). In addition, during the postseason, the decrease in RE was more than the simultaneous decrease in GEP, which also resulted in the recovery of carbon uptake to some degree rested with the degree of drought during the midseason.

The seasonal drought altered the parallel exponential response of monthly GEP and RE to air temperature, and monthly NEP was less sensitive to air temperature than monthly GEP and RE (Fig. 4a). This apparent response emerged through relationships to other processes to which GEP responds more strongly in places where temperature was rarely limiting, namely photosynthetic photon flux density. The exponential response of GEP to air temperature resulted from a logarithm relationship between air temperature and photosynthetic photon flux density, and nonlinear relationship between leaf temperature and GEP. Note that the GEP at half-hourly intervals could be descried using the Michaelis-Menten equation. Reichstein et al. (2007) pointed out that NEP was less sensitive to climate than expected if climate-driven increases or decreases in GEP or RE are met with compensatory behavior in the other term.

The optimum for GEP and RE were usually found at intermediate soil water contents and the GEP and RE decreased at soil water contents either higher or lower than the optimum during higher air temperature (Fig. 5a and b). Since water contents of soils were not in their optimal ranges under most natural conditions in this plantation, considerations of soil water effect in the relationships between GEP, RE and NEP and environmental elements were critical for accurate prediction of global climate change scenarios.

\subsection{Coupling relationship between GEP and RE}

The RE/GEP ratio is useful diagnostics in studies of interannual variability (Valentini et al., 2000; Law et al., 2002). Table 2 gives the ratios of RE to GEP from 2003 to 2007. Table 3 gives the ratios of RE to GEP among different ecosystems with at least 5 years records. The standard deviation showed significantly interannual variability in NEP, resulting from the differential effects of climatic variability or disturbance on GEP and RE (Table 3). With higher carbon uptake capacity, the RE/GEP ratio in this study was mostly lower than other ecosystems except for Tharandt, Takayama, Fujiyoshida and Howard Springs sites (Table 3). Law et al. (2002) reported a range in RE/GEP across a broad diversity of terrestrial ecosystems from 0.55 to 1.2 , with means of 0.82 for deciduous broadleaf forest and 0.85 for coniferous forest. Many of the boreal and northern temperate forests had RE/GEP ratios that exceeded 1.0. Valentini et al. (2000) found a strong dependence of RE/GEP on latitude across a north-south transect of European forests, ranging from 0.50 for southern forests to 0.90 for northern forests.

Figure 6 demonstrates the relationships between monthly and yearly RE and GEP. In comparison, the dataset cited in Table 3 are also shown. They showed closely positive correlation between RE and GEP at the monthly and yearly scales. It can be argued that year-to-year changes in NEP are associated with simultaneous increases or decreases in GEP and RE (Reichstein et al., 2007; Richardson et al., 2007; Baldocchi, 2008). Even though this ecosystem had experienced significant disturbance of seasonal drought, the slope between GEP and RE was very similar to that of the regression on the basis of data from the European (Janssens et al., 2001) and FLUXNET network (Baldocchi, 2008). However, Fig. 6b 
Table 3. Comparison of ecosystem carbon exchanges $\left(\mathrm{g} \mathrm{C} \mathrm{m}^{-2} \mathrm{yr}^{-1}\right)$ among different ecosystems with at least 5 years records. The values in the bracket indicate the standard deviation.

\begin{tabular}{|c|c|c|c|c|c|c|c|c|c|c|c|c|c|}
\hline Site & Latitude & Longitude & Vegetation & GEP & $\mathrm{RE}$ & NEP & RE/GEP & $\begin{array}{l}\text { Temperature } \\
\left({ }^{\circ} \mathrm{C}\right)\end{array}$ & $\begin{array}{l}\text { Precipitation } \\
(\mathrm{mm})\end{array}$ & $\begin{array}{l}\text { Age } \\
(\mathrm{yr})\end{array}$ & $\begin{array}{l}\text { LAI } \\
\left(\mathrm{m}_{2} \mathrm{~m}^{-2}\right)\end{array}$ & Period & Literature \\
\hline NOBS site & $55.88^{\circ} \mathrm{N}$ & $98.48^{\circ} \mathrm{W}$ & $\begin{array}{l}\text { Deciduous } \\
\text { and } \\
\text { evergreen } \\
\text { boreal } \\
\text { forest }\end{array}$ & $706(57)$ & $713(79)$ & $-2(41)$ & $1.01(0.06)$ & -3.2 & 420 & 160 & 4.2 & 1994-2004 & $\begin{array}{l}\text { Dunn et } \\
\text { al., } \\
2007\end{array}$ \\
\hline SOA site & $53.63^{\circ} \mathrm{N}$ & $106.20^{\circ} \mathrm{W}$ & $\begin{array}{l}\text { Deciduous } \\
\text { and } \\
\text { evergreen } \\
\text { boreal } \\
\text { forest }\end{array}$ & $1255(135)$ & $1083(103)$ & $182(94)$ & $0.87(0.06)$ & 1.3 & 484 & 73 & 5.8 & 1994-2003 & $\begin{array}{l}\text { Barr et } \\
\text { al., } \\
2007\end{array}$ \\
\hline Tharandt & $50.96^{\circ} \mathrm{N}$ & $13.57^{\circ} \mathrm{E}$ & $\begin{array}{l}\text { Temperate } \\
\text { coniferous } \\
\text { forest }\end{array}$ & 1845 (154) & $1295(95)$ & $550(87)$ & $0.70(0.03)$ & 8.5 & 833 & 122 & 7.6 & 1996-2005 & $\begin{array}{l}\text { Grünwald } \\
\text { et al., } \\
2007\end{array}$ \\
\hline Hegyhátsál & $49.95^{\circ} \mathrm{N}$ & $16.65^{\circ} \mathrm{E}$ & $\begin{array}{l}\text { Herbaceous/ } \\
\text { shrubland }\end{array}$ & $1096(180)$ & $1061(35)$ & $35(59)$ & $0.98(0.06)$ & 9.9 & 679 & - & - & 1997-2004 & $\begin{array}{l}\text { Haszpra } \\
\text { et al., } \\
2005\end{array}$ \\
\hline \multirow[t]{2}{*}{ Western hemlock } & $49.87^{\circ} \mathrm{N}$ & $125.29^{\circ} \mathrm{W}$ & Clearcut & $521(258)$ & 1097 (234) & $-577(75)$ & $2.52(1.13)$ & 8.9 & 1241 & 5 & 0.8 & $2001-2005$ & $\begin{array}{l}\text { Schwalm } \\
\text { et al., } \\
2007\end{array}$ \\
\hline & $49.87^{\circ} \mathrm{N}$ & $125.29^{\circ} \mathrm{W}$ & $\begin{array}{l}\text { Temperate } \\
\text { coniferous } \\
\text { forest }\end{array}$ & $2076(122)$ & $1784(155)$ & $293(61)$ & $0.86(0.03)$ & 8.4 & 1293 & 56 & 8.4 & 1998-2005 & \\
\hline Howland Forst & $45.25^{\circ} \mathrm{N}$ & $68.73^{\circ} \mathrm{W}$ & $\begin{array}{l}\text { Deciduous } \\
\text { and } \\
\text { evergreen } \\
\text { boreal } \\
\text { forest }\end{array}$ & $1343(95)$ & $1168(80)$ & $174(45)$ & $0.87(0.03)$ & 6.7 & 1040 & 100 & 4.7 & 1996-2002 & $\begin{array}{l}\text { Hollinger } \\
\text { et al., } \\
2004\end{array}$ \\
\hline \multirow[t]{3}{*}{ Harvard Forest } & $42.54^{\circ} \mathrm{N}$ & $72.17^{\circ} \mathrm{W}$ & $\begin{array}{l}\text { Temperate } \\
\text { deciduous } \\
\text { forst }\end{array}$ & $1166(79)$ & $962(118)$ & $224(56)$ & $0.82(0.05)$ & - & - & - & - & 1991-1995 & $\begin{array}{l}\text { Goulden } \\
\text { et al., } \\
1996\end{array}$ \\
\hline & & & & 1297 (99) & $1099(91)$ & 201 (36) & $0.85(0.03)$ & - & - & - & - & 1992-2000 & $\begin{array}{l}\text { Barford } \\
\text { et al., } \\
2001\end{array}$ \\
\hline & & & & $1440(164)$ & $1153(105)$ & $245(100)$ & $0.83(0.05)$ & 8.3 & 1066 & $75 \sim 100$ & 4.7 & 1992-2004 & $\begin{array}{l}\text { Urbanski } \\
\text { et al., } \\
2007\end{array}$ \\
\hline Tonzi Ranch & $38.43^{\circ} \mathrm{N}$ & $120.96^{\circ} \mathrm{W}$ & $\begin{array}{l}\text { Herbaceous/ } \\
\text { shrubland }\end{array}$ & $1070(193)$ & $972(51)$ & $98(51)$ & $0.91(0.05)$ & 16.5 & 562 & - & 0.6 & 2002-2006 & $\begin{array}{l}\text { Ma et } \\
\text { al., } \\
2007\end{array}$ \\
\hline Vaira Ranch & $38.41^{\circ} \mathrm{N}$ & $120.95^{\circ} \mathrm{W}$ & Herbaceous & $926(230)$ & $963(151)$ & $-38(118)$ & $1.07(0.15)$ & 16.5 & 562 & - & 2.4 & 2001-2006 & \\
\hline \multirow[t]{2}{*}{ Takayama } & $36.13^{\circ} \mathrm{N}$ & $137.42^{\circ} \mathrm{E}$ & $\begin{array}{l}\text { Temperate } \\
\text { deciduous } \\
\text { forest }\end{array}$ & $978(120)$ & $742(36)$ & $237(92)$ & $0.76(-)$ & - & - & - & - & 1994-2002 & $\begin{array}{l}\text { Saigusa } \\
\text { et al., } \\
2005\end{array}$ \\
\hline & & & & $1328(260)$ & $1214(290)$ & $112(36)$ & $0.91(0.05)$ & 6.6 & 2033 & 50 & 3.5 & 2000-2004 & $\begin{array}{l}\text { Hirara } \\
\text { et al., } \\
2008\end{array}$ \\
\hline Fujiyoshida & $35.45^{\circ} \mathrm{N}$ & $135.98^{\circ} \mathrm{E}$ & $\begin{array}{l}\text { Temperate } \\
\text { coniferous } \\
\text { forest }\end{array}$ & $1634(149)$ & $1274(96)$ & $360(86)$ & $0.78(0.04)$ & 9.6 & 2055 & 90 & 5.5 & 2000-2004 & \\
\hline Qianyanzhou & $26.75^{\circ} \mathrm{N}$ & $115.06^{\circ} \mathrm{E}$ & $\begin{array}{l}\text { Subtropical } \\
\text { coniferous } \\
\text { plantation }\end{array}$ & 1779 (107) & $1384(75)$ & $395(50)$ & $0.78(0.02)$ & 18.5 & 1185.3 & 23 & 5.6 & 2003-2007 & $\begin{array}{l}\text { This } \\
\text { study }\end{array}$ \\
\hline Howard Springs & $12.68^{\circ} \mathrm{S}$ & $131.15^{\circ} \mathrm{E}$ & $\begin{array}{l}\text { Subtropical } \\
\text { Savanna }\end{array}$ & $1378(87)$ & $1022(43)$ & $358(78)$ & $0.74(0.04)$ & 27.1 & 1824 & - & 1.0 & 2001-2005 & $\begin{array}{l}\text { Beringer } \\
\text { et al., } \\
2007\end{array}$ \\
\hline
\end{tabular}

showed, on the annual time scale, the slope between GEP and RE in this study was more sensitive to the GEP and RE of the severe drought year (2003) and the water excess year (2005).

\subsection{Water balance controls over interannual variations in GEP, RE and NEP}

$P$-ET is an index of surplus precipitation, and also a reasonable estimate of water balance (Law et al., 2002), but it could underestimate the intensity of water stress because runoff components could be the potential errors resources. Figure 7 demonstrates the relationships between yearly GEP and RE and site water balance ( $P$-ET), and between yearly NEP and site water balance index $P / E T$. The results highlighted that annual GEP, RE and NEP totals were linked to the site water balance. The quadratic function best described the dependence of ecosystem carbon exchanges on factors related to water balance in this humid climate zone. The optimum for GEP, RE and NEP were found at intermediate water balances, and they decreased at water balances either higher or lower than the optimum. In comparison, yearly NEP increased linearly with air temperature, but yearly GEP and RE had no correlation with air temperature (Fig. 4b). Carbon assimilation and plant growth were suppressed while the water 

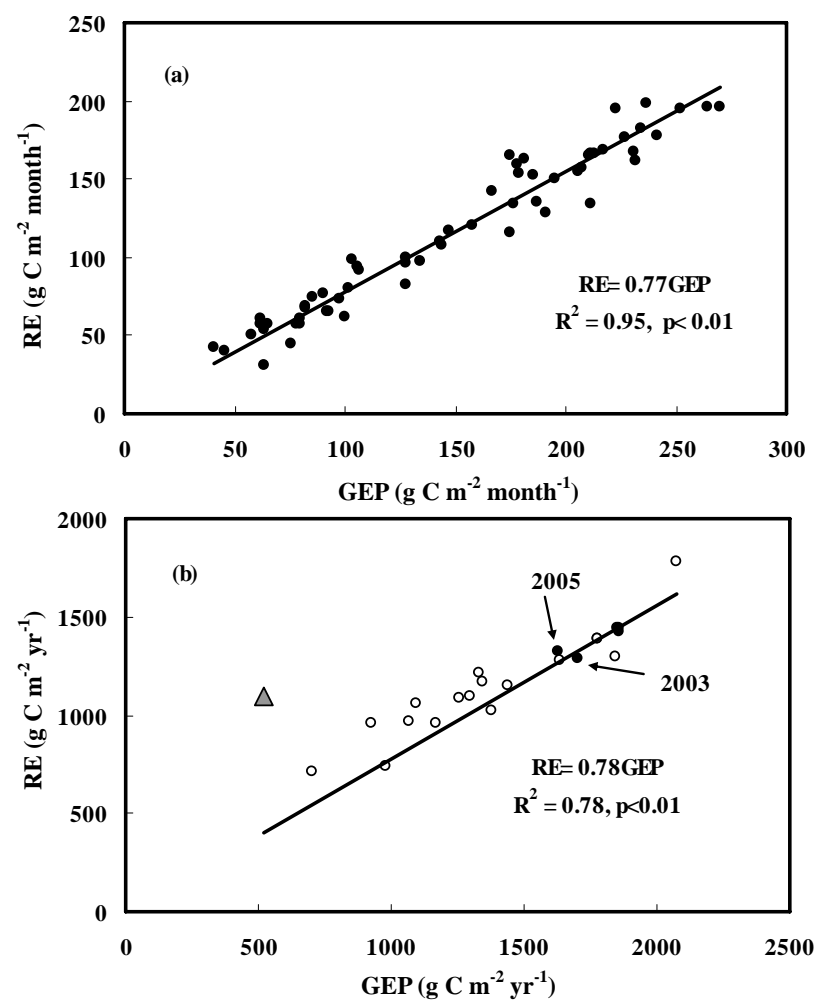

Fig. 6. The dependence of (a) monthly and (b) yearly ecosystem respiration (RE) on gross ecosystem photosynthesis (GEP) during 2003 to 2007 at Qianyanzhou site. The linear regression lines were shown for the monthly and yearly dataset of Qianyanzhou site. The dataset cited in Table 3 are shown as blank circles and triangle (clearcut) for comparison.

consumption was much smaller than water supply. For example, lower net carbon uptake in 2005 was caused due to low temperatures and excess cloudiness accompanying with the reduced photosynthesis exceeding the reduced respiration. However, carbon assimilation and plant growth were also suppressed during the summer drought resulting from the inconsistent distribution of precipitation and temperature. Severe drought (e.g. in 2003) caused a little reduction in annual NEP mainly due to higher NEP during the preseason resulting from higher water availability. Moderate drought in 2007 led to an additional carbon uptake because of increasing GEP and retarding RE during the postseason. This unexpected result occurred because less rain was associated with fewer clouds, which made more available light duration and increased GEP.

Figure 8 demonstrates the relationships between the ratios of yearly RE to GEP and air temperature and site water balance index $P / \mathrm{ET}$. Interannual variability in the RE/GEP ratios was controlled primarily by air temperature, and by factors related to the site water balance. Statistical analysis suggested that factors related to the water balance might override the effects of temperature on annual ecosystem car-
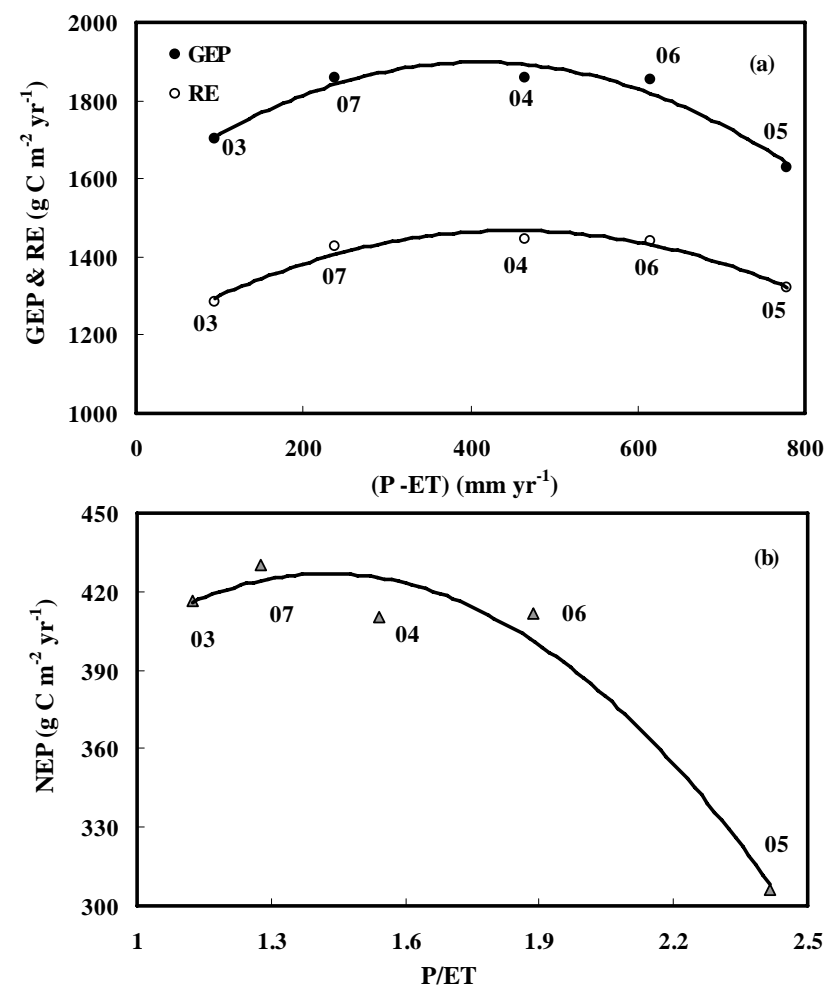

Fig. 7. The relationships (a) between yearly gross ecosystem photosynthesis (GEP), ecosystem respiration (RE) and water balance $(P$ ET), and (b) between yearly net ecosystem production (NEP) and water balance index (P/ET) during 2003 to 2007 at Qianyanzhou site. Least-squares quadratic regressions were given by the solid line, and (a) GEP: $R^{2}=0.94, p<0.01$ and RE: $R^{2}=0.96, p<$ 0.01 , and (b) $R^{2}=0.96, p<0.01$.

bon balance. Ecosystem water balances are changing due to altered rainfall and evaporation patterns (Rambal and Debussche, 1995; Waple and Lawrimore, 2003). This result also highlighted the possibility that with respect to changing climate the variations in rainfall and evaporation patterns might affect ecosystem carbon balance complexly. Thus, special attention should be given to the coupling of carbon and water cycles. Most predictions of the response of terrestrial ecosystem to climatic warming focus on the increase in temperature, but ignore the possibility that ecosystem carbon exchange may be especially sensitive to seasonal distribution of precipitation (e.g. drought) during specific intervals of the year (Goulden et al., 1996; Reichstein et al., 2007). The long-term ecosystem water balance was clearly important, and might explain the observed interannual variability and trend of GEP, RE and NEP. Nonetheless, the factors related to the ecosystem water balance may have key implications for ecosystem resistance and resilience in the face of changes in climate or climate variability (e.g. Dunn et al., 2007). 


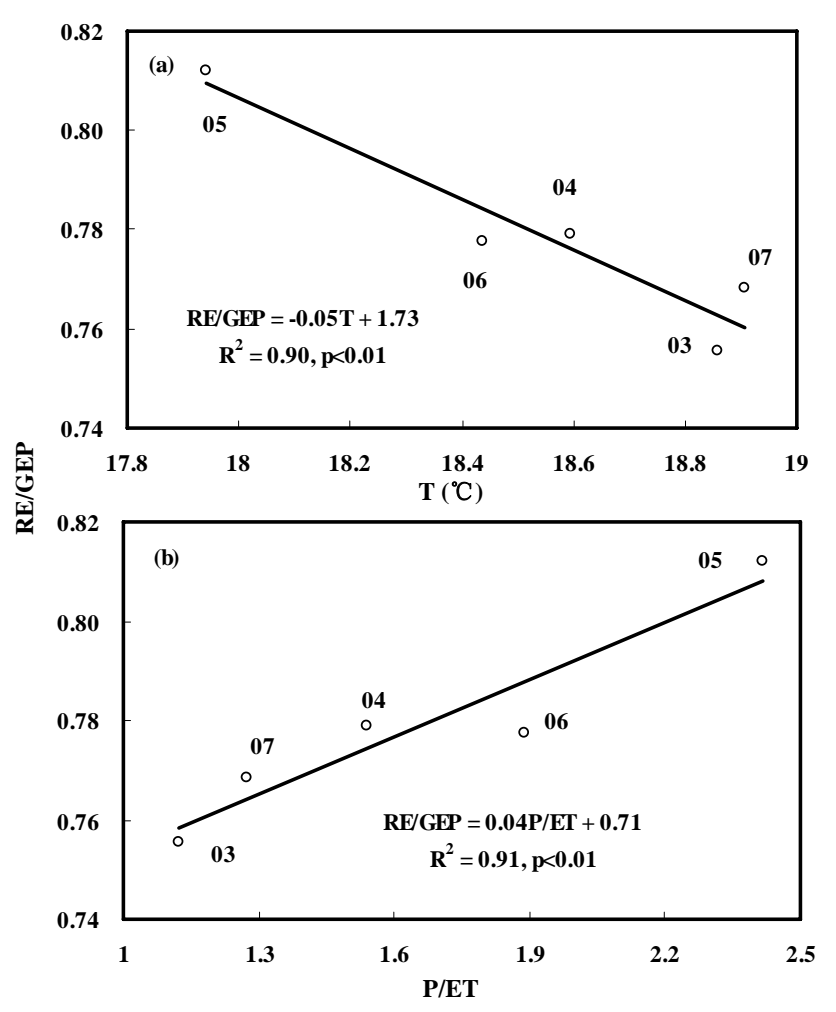

Fig. 8. The dependence of the ratios of yearly ecosystem respiration (RE) to gross ecosystem photosynthesis (GEP) on (a) air temperature $(T)$ and (b) water balance index $(P / E T)$ during 2003 to 2007 at Qianyanzhou site. The linear regression lines were shown.

\subsection{Comparison of ecosystem carbon exchanges with other forests}

Some flux studies with at least 5 years data had been published. Table 3 lists the interannual variation of ecosystem carbon exchanges among different ecosystems with at least 5 years records. Ecosystem carbon sequestration of this subtropical evergreen coniferous plantation was similar to that of the temperate coniferous forest at Fujiyoshida site, and the subtropical savanna at Howard Springs site. Year to year variability of ecosystem carbon sequestration was lower than that of Fujiyoshida and Howard Springs. Note that there was obviously different in yearly GEP and RE among the three sites. Yearly GEP and RE of this subtropical plantation were higher than that of Fujiyoshida and Howard Springs mainly because of the whole year growing season. The maximum leaf area index was $5.6 \mathrm{~m}^{2} \mathrm{~m}^{-2}$, varying less than $1.5 \mathrm{~m}^{2} \mathrm{~m}^{-2}$ during the whole year growing season (Huang et al., 2007). Ecosystem carbon sequestration of this subtropical plantation was also higher than that of other ecosystems except for that of the temperate coniferous forest at Tharandt site.

In addition, there were relative few studies in the subtropical humid zone. In a naturally regenerated longleaf pine/slash pine flatwoods plantation $\left(29^{\circ} 44^{\prime} \mathrm{N}, 82^{\circ} 09^{\prime} \mathrm{E}\right)$, the annual NEP ranged from 158 to $192 \mathrm{~g} \mathrm{C} \mathrm{m}^{-2} \mathrm{yr}^{-1}$ among the four measurement years (Powell et al., 2008). The annual NEP was obviously lower than the annual NEP in this plantation, which ranged from 306 to $430 \mathrm{~g} \mathrm{C} \mathrm{m}^{-2} \mathrm{yr}^{-1}$ among the five measurement years.

These differences may be related to climate type, ages, structure, and plant ecophysiological characteristics of different forests (e.g. Law et al., 2002; Griffis et al., 2003). Baldocchi (2008) pointed that evergreen mid-age forest, year-round growing seasons and small pool of decomposing detritus on the soil would result in the maximum amounts of net carbon sequestration, and maximum amounts occur when the forests are between 50 and 100 years old. It indicated that more carbon uptake would be possible because this subtropical coniferous plantation was planted in 1985, with a small pool of decomposing detritus (Huang et al., 2007; Wang et al., 2009).

\section{Conclusions}

In this paper, the magnitude and cause of both seasonal and interannual variations in GEP, RE and NEP subjected to seasonal drought were investigated in the 5-year study period (2003-2007). The main findings are summarized as follows: 1) NEP and its components (i.e. GEP and RE) showed clear seasonality, with low rates varying with drought severity and history during summer and in winter. 2) The monthly GEP and RE increased exponentially with air temperature, but monthly NEP increased linearly with air temperature. Under high temperature and low soil moisture, the function response of monthly NEP, GEP and RE disappeared. 3) Monthly and yearly RE showed a linear and positive dependence on the corresponding GEP. Seasonal and interannual variability in NEP was controlled by the factors such as drought that affected GEP and RE differently. 4) Yearly GEP and RE were related with site water balance $(P$-ET), and yearly NEP was correlated with air temperature and the related water balance index $P / E T$. 5) Annual GEP, RE and NEP varied from 1629 to $1857 \mathrm{~g} \mathrm{C} \mathrm{m}^{-2}, 1286$ to $1447 \mathrm{~g} \mathrm{C} \mathrm{m}^{-2}$, and 306 to $430 \mathrm{~g} \mathrm{C} \mathrm{m}^{-2}$, respectively. In our future work, we will continue to explore this dataset on the increased rainfall variability due to low annual rainfall and altered rainfall and evaporation patterns, which could be likely to have complicated effects on ecosystem carbon exchanges of this subtropical plantation.

Acknowledgements. This study was supported by the National Natural Science Foundation of China (30670384, 30800151 and 30721140307), Knowledge Innovation Project (KZCX2YW-432) and Ministry of Science and Technology of China (2010CB833501), and Hundred Talents Program of the Chinese Academy of Sciences.

Edited by: T. Hirano 


\section{References}

Aubinet, M., Grelle, A., Ibrom, A., Rannik, U., Moncrieff, J., Foken, J., Kowalski, A. S., Martin, P. H., Berbigier, P., Bernhofer, C., Clement, R., Elbers, J., Granier, A., Grunwald, T., Morgenstern, K., Pilegaard, K., Rebmann, C., Snijders, W., Valentini, R., and Vesala, T.: Estimates of the annual net carbon and water exchange of forests: the Euroflux methodology, Adv. Ecol. Res., 30, 113-175, 2000.

Baldocchi, D., Falge, E., and Wilson, K.: A spectral analysis of biosphere-atmosphere trace gas flux densities and meteorological variables across hour to multi-year scales, Agr. Forest Meteorol., 107, 1-27, 2001.

Baldocchi, D.: "Breathing" of the terrestrial biosphere: lessons learned from a global network of carbon dioxide flux measurement systems, Australian Journal of Botany, 56, 1-26, 2008.

Baldocchi, D.: Assessing the eddy covariance technique for evaluating carbon dioxide exchange rates of ecosystems: past, present and future, Glob. Change Biol., 9, 479-492, 2003.

Baldocchi, D.: Measuring and modeling carbon dioxide and water vapour exchange over a temperature broad-leaved forest during the 1995 summer drought, Plant Cell Environ., 20, 1108-1122, 1997.

Baldocchi, D.: The carbon cycle under stress, Nature, 437, 483484, 2005.

Barford, C. C., Wofsy, S. C., Goulden, M. L., Munger, J. W., Pyle, E. H., Urbanski, S. P., Hutyra, L., Saleska, S. R., Fitzjarrald, D., and Moore, K.: Factors controlling long- and short-term sequestration of atmospheric $\mathrm{CO}_{2}$ in a mid-latitude forest, Science, 294, 1688-1691, 2001.

Barr, A. G., Black, T. A., Hogg, E. H., Griffis, T. J., Morgenstern, K., Kljun, N., Theede, A., and Nesic, Z.: Climatic controls on the carbon and water balances of a boreal aspen forest, 1994-2003, Glob. Change Biol., 13, 561-576, 2007.

Beniston, M.: The 2003 heat wave in Europe: A shape of things to come? An analysis based on Swiss climatological data and model simulations, Geophys. Res. Lett., 31, L02202, doi:10.1029/2003GL018857, 2004.

Beringer, J., Hutley, L. B., Tapper, N. J., and Cernusak, L. A.: Savanna fires and their impact on net ecosystem productivity in north Australia, Glob. Change Biol., 13, 990-1004, 2007.

Ciais, P., Reichstein, M., Viovy, N., Granier, A., Ogée, J., Allard, V., Aubinet, M., Buchmann, N., Bernhofer, C., Carrara, A., Chevallier, F., De Noblet, N., Friend, A. D., Friedlingstein, P., Grünwald, T., Heinesch, B., Keronen, P., Knohl, A., Krinner, G., Loustau, D., Manca, G., Matteucci, G., Miglietta, F., Ourcival, J. M., Papale, D., Pilegaard, K., Rambal, S., Seufert, G., Soussana, J. F., Sanz, M. J., Schulze, E. D., Vesala, T., and Valentini, R.: Europe-wide reduction in primary productivity caused by the heat and drought in 2003, Nature, 437, 529-533, 2005.

Dunn, A. L., Barford, C. C., Wofsy, S. C., Goulden, M. L., and Daube, B. C.: A long term record of carbon exchange in a boreal black spruce forest: means, responses to interannual variability, and decadal trends, Glob. Change Biol., 13, 577-590, 2007.

Falge, E., Baldocchi, D., Olson, R., Anthoni, P., Aubinet, M., Bernhofer, C., Burba, G., Ceulemans, R., Clement, R., Dolman, H., Granier, A., Gross, P., Grünwald, T., Hollinger, D., Jensen, N. O., Katul, G., Keronen, P., Kowalski, A., Laim, C. T., Law, B. E., Meyers, T., Moncrieff, J., Moors, E., Munger, J. W., Pilegaard, K., Rannik, Ü., Rebmann, C., Suyker, A., Tenhunen, J., Tu, K.,
Verma, S., Vesala, T., Wilson, K., and Wofsy, S.: Gap filling strategies for defensible annual sums of net ecosystem exchange, Agr. Forest Meteorol., 107, 43-69, 2001.

Foken, T. and Wichura, B.: Tools for quality assessment of surfacebased flux measurements, Agr. Forest Meteorol., 78, 83-105, 1996.

Goulden, M. L., Munger, J. W., Fan, S. M., Daube, B. C., and Wofsy, S. C.: Exchange of carbon dioxide by a deciduous forest: response to interannual climate variability, Science, 271, 15761578, 1996.

Griffis, T. J., Black, T. A., Morgenstern, K., Barr, A. G., Nesic, Z., Drewitt, G. B., Gaumont-Guaya, D., and McCaughey, J. H.: Ecophysiological controls on the carbon balances of three southern boreal forests, Agr. Forest Meteorol., 117, 53-71, 2003.

Grünwald, T. and Bernhoffer, C.: A decade of carbon, water and energy flux measurements of an old spruce forest at the anchor station tharandt, Tellus B, 59, 387-396, 2007.

Haszpra, L., Barcza, Z., Davis, K. J., and Tarczay, K.: Long-term tall tower carbon dioxide flux monitoring over an area of mixed vegetation, Agr. Forest Meteorol., 132, 58-77, 2005.

Hirata, R., Saigusa, N., Yamamoto, S., Ohtani, Y., Ide, R., Asanuma, J., Gamo, M., Hirano, T., Kondo, H., Kosugi, Y., Li, S. G., Nakai, Y., Takagi, K., Tani, M., and Wang, H. M.: Spatial distribution of carbon balance in forest ecosystems across East Asia, Agr. Forest Meteorol., 148, 761-775, 2008.

Hollinger, D. Y., Aber, J., Dail, B., Davidson, E. A., Goltz, S. M., Hughes, H., Leclerc, M. Y., Lee, J. T., Richardson, A. D., Rodrigues, C., Scott, N. A., Achuatavarier, D., and Walsh, J.: Spatial and temporal variability in forest-atmosphere $\mathrm{CO}_{2}$ exchange, Glob. Change Biol., 10, 1689-1706, 2004.

Huang, M., Ji, J. J., LI, K. R., Liu, Y. F., and Yang, F. T.: The ecosystem carbon accumulation after conversion of grasslands to pine plantations in subtropical red soil of South China, Tellus, 59B, 439-448, 2007.

Janssens, I. A., Lankreijer, H., Matteucci, G., Kowalski, A. S., Buchmann, N., Epron, D., Pilegaard, K., Kutsch, W., Longdoz, B., Grünwald, T., Montagani, L., Dore, S., Rebmann, C., Moors, E. J., Grelle, A., Ranik, Ü., Morgenstern, K., Oltchev, S., Clement, R., Guðmundsson, J., Minerbi, S., Berbigier, P., Ibrom, A., Moncrieff, J., Aubinet, M., Bernhofer, C., Jensen, N. O., Vesala, T., Granier, A., Schulze, E. D., Libdroth, A., Dolman, A. J., Javis, P. G., Ceulemans, R., and Valentini, R.: Productivity overshadows temperature in determining soil and ecosystem respiration across European forest, Glob. Change Biol., 7, 269-278, 2001.

Kaimal, J. C., Wyngaard, J. C., Izumi, Y., and Cote, O. R.: Spectral characteristics of surface-layer turbulence, Q. J. Roy. Meteorol. Soc., 98, 563-589, 1972.

Karl, T. R., Knight, R. W., and Plummer, N.: Trends in high frequency climate variability in the twentieth century, Nature, 377 , 217-220, 1995.

Law, B. E., Falge, E., Gu, L., Baldocchi, D., Bakwin, P., Berbigier, P., Davis, K., Dolman, A. J., Falk, M., Fuentes, J. D., Goldstein, A., Granier, A., Grelle, A., Hollinger, D., Janssens, I. A., Jarvis, P., Jensen, N. O., Katul, G., Mahli, Y., Matteucci, G., Meyers, T., Monson, R., Munger, W., Oechel, W., Olson, R., Pilegaard., Paw U, K. T., Thorgeirsson, H., Valentini, R., Verma, S., Vesala, T., Wilson, K., and Wofsy, S.: Environmental controls over carbon dioxide and water vapor exchange of terrestrial vegetation, Agr. 
Forest Meteorol., 113, 97-120, 2002.

Leuning, R.: Measurements of trace gas fluxes in the atmosphere using eddy covariance: WPL corrections revisited, in: Handbook of Micrometeorology: A guide for surface flux measurement and analysis, edited by: Lee, X., Massman, W., and Law, B., Kluwer Academic Publisher, Dordrecht, 119-132, 2004.

Ma, S., Baldocchi, D., Xu, L., and Hehn, T.: Inter-annual variability in carbon dioxide exchange of an oak/grass savanna and open grassland in California, Agr. Forest Meteorol., 147, 157171, 2007.

Ma, Z. Q., Liu, Q. J., Wang, H. M., Li, X. R., Zeng, H. Q., and $\mathrm{Xu}$, W. J.: Observation and modeling of NPP for Pinus elliottii plantation in subtropical China, Sci. China Ser. D-Earth, 51, 955-965, 2008.

Meehl, G. A. and Tebaldi, C.: More intense, more frequent, and longer lasting heat waves in the 21 st century, Science, 305, 994997, 2004.

Mi, N., Yu, G. R., Wen, X. F., Sun, X. M., Wang, S. Zhang, L. M., and Song, X.: Use of ecosystem flux data and a simulation model to examine seasonal drought effects on a subtropical coniferous forest, Asia-Pacific Journal of Atmospheric Sciences, 45, 207220, 2009.

Moore, C. J.: Frequency response corrections for eddy correlation systems, Bound.-Lay. Meteorol., 37, 17-35, 1986.

Niu, S. L., Wu, M. Y., Han, Y., Xia, J. Y. Li, L. H., and Wan, S. Q.: Water-mediated response of ecosystem carbon fluxes to climatic change in a temperate steppe, New Phytol., 177, 209-219, 2008.

Papale, D., Reichstein, M., Aubinet, M., Canfora, E., Bernhofer, C., Kutsch, W., Longdoz, B., Rambal, S., Valentini, R., Vesala, T., and Yakir, D.: Towards a standardized processing of Net Ecosystem Exchange measured with eddy covariance technique: algorithms and uncertainty estimation, Biogeosciences, 3, 571-583, 2006 ,

http://www.biogeosciences.net/3/571/2006/.

Powell, T. L., Gholz, H. L., Clark, K. L., Starr, G., Cropper Jr., W. P., and Martin, T. A.: Carbon exchange of a mature, naturally regenerated pine forest in north Florida, Glob. Change Biol., 14, 2523-2538, 2008.

Rambal, S. and Debussche, G.: Water balance of Mediterranean ecosystem under a changing climate, in: Global Change and Mediterranean-Type Ecosystems, edited by: Moreno, J. M. and Oechel, W. C., Springer, New York, 386-407, 1995.

Reichstein, M., Falge, E., Baldocchi, D., Papale, D., Aubinet, M., Berbigier, P., Bernhofer, C., Buchmann, N., Gilmanov, T., Granier, A., Grünwald, T., Havrámkova, K., Ilvesniemi, H., Janous, D., Knohl, A., Laurila, T., Lohila, A., Loustau, D., Matteucc, G., Meyers, T., Miglietta, F., Ourcival, J. M., Pumpanen, J., Rambal, S., Rotenberg, A.E., Sanz, M., Tenhunen, J., Seufert, G., Vaccari, F., Vesala, T., Yakir, D., and Valentini, R.: On the separation of net ecosystem exchange into assimilation and ecosystem respiration: review and improved algorithm, Glob. Change Biol., 11, 1424-1439, 2005.

Reichstein, M., Papale, D., Valentini, R., Aubnet, M., Bernhofer, C., Knohl, A., Laurila, T., Lindroth, A., Mors, E., Pilegaard, K., and Seufert, G.: Determinant of terrestrial ecosystem carbon exchange inferred from European eddy covariance flux sites, Geophys. Res. Lett., 34, L01402, doi:1029/2006GL027880, 2007.

Reichstein, M., Tenhunen, J. D., Roupsard, O., Ourcival, J. M., Rambal,S., Dore, S., and Valentini, R.: Ecosystem respiration in two Mediterranean veergreen Holm Oak forests: drought effects and decomposition dynamics, Funct. Ecol., 16, 27-39, 2002.

Richardson, A. D. and Hollinger, D. Y.: A method to estimate the additional uncertainty in gap-filled NEE resulting for long gaps in the $\mathrm{CO}_{2}$ flux record, Agr. Forest Meteorol., 147, 199-208, 2007.

Saigusa, N., Yamamoto, S., Murayama, S., and Kondo, H.: Interannual variability of carbon budget components in an asiaflux forest site estimated by long-term flux measurements, Agr. Forest Meteorol., 134, 4-16, 2005.

Schulze, E. D., Wirth, C., and Heimann, M.: Managing forests after Kyoto, Science, 289, 2058-2059, 2000.

Schwalm, C. R., Black, T. A., Morgenstern, K., and Humphreys, E. R.: A method for deriving net primary productivity and component respiratory fluxes from tower based eddy covariance data: a case study using a 17-year data record from a Douglas-fir chronosequence, Glob. Change Biol., 13, 370-385, 2007.

Sun, X. M., Wen, X. F, Yu, G. R., Liu, Y. F., and Liu, Q. J.: Seasonal drought effects on carbon sequestration of a mid-subtropical planted forest of southeastern China, Science in China Ser. D Earth Sciences, 49(S2), 110-118, 2006a.

Sun, X. M., Zhu, Z. L., Wen, X. F., Yuan, G. F., and Yu, G. R.: The impact of averaging periods on eddy fluxes observed over ChinaFLUX sites, Agr. Forest Meteorol., 137, 188-193, 2006 b.

Urbanski, S., Barford, C., Wofsy, S., Kucharik, C., Pyle, E., Budney, J., McKain, K., Fitzjarrald, D., Czikowsky, M., and Munger, J. W.: Factors controlling $\mathrm{CO}_{2}$ exchange on timescales from hourly to decadal at Harvard forest, J. Geophys. Res., 112, G02020, doi:10.1029/2006JG000293, 2007.

Valentini, R., Matteucci, G., Dolman, A. J., Schulze, E. D., Rebmann, C., Moors, E. J., Granier, A., Gross, P., Jensen, N. O., Pilegaard, K., Lindroth, A., Grelle, A., Bernhofer, C., Grunwald, T., Aubinet, M., Ceulemans, R., Kowalski, A. S., Vesala, T., Rannik, U., Berbigier, P., Loustau, D., GuÖmundsson, J., Thorgeirsson, H., Ibrom, A., Morgenstern, K., Clement, R., Moncrieff, J., Montagnani, L., Minerbi, S., and Jarvis, P. G.: Respiration as the main determinant of carbon balance in European forests, Nature, 404, 861-865, 2000.

Vickers, D. and Mahrt, L.: Quality control and flux sampling problems for tower and aircraft data, J. Atmos. Ocean. Tech., 14, 512526, 1997.

Wang, S. Q., Liu, J. Y., Yu, G. R., Pan, Y. Y., Chen, Q. M., Li, K. R., and Li, J. Y.: Effects of land use change on the storage of soil organic carbon: A case study of the Qianyanzhou Forest Experimental Station in China, Climate Change, 67, 247-255, 2004.

Wang, Y. D., Wang, H. M., Ma, Z. Q., Wen, X. F., Li, Q. K., Liu, Y. F., Sun, X. M., and Yu, G. R.: Contribution of aboveground litter decomposition to soil Respiration in a subtropical coniferous plantation in Southern China, Asia-Pacific Journal of Atmospheric Sciences, 45, 137-147, 2009.

Waple, A. M. and Lawrimore, J. H.: State of the climate in 2002, B. Am. Meteorol. Soc., 84, p. 800, 2003.

Webb, E. K., Pearman, G. L., and Leuning, R.: Correction of flux measurements foe density effects due to heat and water vapour transfer, Q. J. Roy. Meteor. Soc., 106, 85-100, 1980.

Wen, X. F., Yu, G. R., Sun, X. M., Li, Q. K., Lui, Y. F., Zhang, L. M., Ren, C. Y., Fu, Y. L., and Li, Z. Q.: Soil moisture effect on the temperature dependence of ecosystem respiration in 
a subtropical Pinus plantation of southeastern China, Agr. Forest Meteorol.,137, 166-175, 2006.

Wen, X. F., Yu, G. R., Sun, X. M., and Liu, Y. F.: Turbulence flux measurement above the overstory of a subtropical Pinus plantation over the hilly region in southeastern China, Science in China Series D: Earth Sciences, 48(SI), 63-73, 2005.

Wilczak, J. M., Oncley, S. P., and Stage, S. A.: Sonic anemometer tilt correction algorithms, Bound.-Lay. Meteorol., 99, 127-150, 2001.

Yu, G. R., Song, X., Wang, Q. F., Liu, Y. F., Guan, D. X., Yan, J. H., Sun, X. M., Zhang, L. M., and Wen, X. F.: Water-use efficiency of forest ecosystems in eastern China and its relations to climatic variables, New Phytol., 177, 927-937, 2008a.
Yu, G. R., Wen, X. F., Tanner, B. D., Sun, X. M., Lee, X. H., and Chen, J. Y.: Overview of ChinaFLUX and evaluation of its eddy covariance measurement, Agr. Forest Meteorol., 137, 125-137, 2006.

Yu, G. R., Zhang, L. M., Sun, X. M., Fu, Y. L., Wen, X. F., Wang, Q. F., Li, S. G., Ren, C. Y., Song, X., Liu, Y. F., Han, S. J., and Yan, J. H.: Environmental controls over carbon exchange of three forest ecosystems in eastern China, Glob. Change Biol., 14, 2555-2571, 2008b. 